Research Article

\title{
Pharmacoeconomic analysis of drugs used for peptic ulcer in India
}

\author{
Bhanu Prakash Kolasani*, C. M. Divyashanthi
}

Department of Pharmacology, Vinayaka Missions Medical College and Hospital, Karaikal India

Received: 18 June 2016

Accepted: 08 July 2016

\section{*Correspondence to:}

Dr. Bhanu Prakash Kolasani, Email: kolasanibhanu@ yahoo.co.in

Copyright: () the author(s), publisher and licensee Medip Academy. This is an openaccess article distributed under the terms of the Creative Commons Attribution NonCommercial License, which permits unrestricted noncommercial use, distribution, and reproduction in any medium, provided the original work is properly cited.

\begin{abstract}
Background: Acid peptic disorders are common medical problems in daily clinical practice leading to a significant economic burden on healthcare expenses. Due to lack of information on comparative drug prices and quality, it becomes difficult for physicians to prescribe the most economical treatment. So the present study was planned to analyse the price variations of various antiulcer drugs available in India.

Methods: The cost of a particular anti-ulcer drug being manufactured by different companies, in the same dose and dosage forms, was obtained from latest issue of "current index of medical specialties" January to April, 2016. The difference between the maximum and minimum prices of same drug was analysed and percentage variation in the prices was calculated.

Results: Overall, the prices of a total of 12 anti-ulcer drugs belonging to four different categories available in 38 different formulations were analysed. Among the proton pump inhibitors, pantoprazole (40 mg; EC tablet) showed the maximum price variation of $500.75 \%$. With regard to $\mathrm{H} 2$ blockers, ranitidine (50 $\mathrm{mg}$; injection) showed the maximum price variation of $989.92 \%$. The maximum price variation among various formulations of ulcer protective was seen with sucralfate $(1000 \mathrm{mg}$; tablet) of $166.00 \%$ while misoprostol $(200 \mu \mathrm{g}$; tablet) was the only drug present in prostaglandin analogues and it showed a price variability of $14.33 \%$.

Conclusions: The average percentage variations of different brands of the same anti-ulcer drugs in same dose and dosage form manufactured in India were very wide. The government and drug manufacturing companies must direct their efforts in reducing the cost of anti-ulcer drugs and thereby minimizing the economic burden on the patients.
\end{abstract}

Keywords: Cost analysis, Proton pump inhibitors, $\mathrm{H} 2$ blockers, Ulcer protective

\section{INTRODUCTION}

Acid peptic disorders are the result of distinctive, but overlapping pathogenic mechanisms leading to either excessive acid secretion or diminished mucosal defence. Peptic ulcers occur mainly in the stomach-gastric ulcer or proximal duodenum - duodenal ulcer. They are common medical problems in daily clinical practice that, owing to their chronicity, represent a significant cost to healthcare. Acid-related disorders influence the quality of life and productivity of afflicted patients and are common and important causes of morbidity and mortality. ${ }^{1}$ Approximately $40 \%$ of adults in the USA complain of monthly some form of heartburn making them one the most common gastrointestinal disorders with resultant costs of more than US $\$ 10$ billion per year. ${ }^{2,3}$
Various drugs are available for treating peptic ulcer like proton pump inhibitors (PPIs), H2 blockers, antacids, ulcer protectives and prostaglandin analogues. In developed countries, where a system of medical insurance is in place, it may not be a concern but in developing countries like India, where the medical insurance is only in an emerging stage, affordability to anticancer drugs becomes a major concern. ${ }^{4}$ The compliance of the patient also is significantly dependent on the cost of the prescribed medicines and higher cost means the compliance will be less. ${ }^{5}$

Pharmaceutical market in India has over 20,000 medicine formulations and majority of them are sold under brand names. ${ }^{6,7}$ Indian markets are flooded with a huge number of formulations of anti-ulcer drugs, and the same formulations are sold under different brands which puts 
the prescribing physicians in difficult state in deciding the best drug for a given patient. ${ }^{8}$

Information generated from cost analysis studies will be helpful for both the doctors in choosing the correct medicine for their patients and for policy makers in successfully utilizing the meagre resources that are available. ${ }^{9}$ A med line search was done for studies which analysed the variation of prices among anti-ulcer drugs and it did not yield any positive result. So the present study was done to analyse the variation of cost among different brands of anti-ulcer drugs available in the Indian market.

\section{METHODS}

The study was done in the department of pharmacology of a tertiary care teaching hospital in south India. Latest volume of current index of medical specialities (CIMS) i.e. January to April, 2016 was used to analyse the prices of anticancer drugs.

The cost of a particular anti-ulcer drug in the same dose and dosage forms being manufactured by different companies was compared. The drugs manufactured by only one company or by different companies, however, in different strengths were excluded. Formulations containing combination of drugs were also excluded. The difference between the maximum and minimum costs of the same drug manufactured by different pharmaceutical companies was calculated. The following formula was used to calculate the price variation.

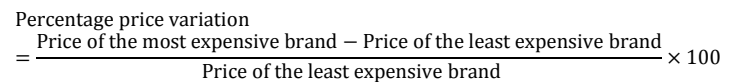

\section{Statistical analysis}

The findings of our observational study were expressed as absolute numbers and percentages.

\section{RESULTS}

The prices of a total of 12 anti-ulcer drugs belonging to four different categories available in 38 different formulations were analysed.

Table 1: Price variation among proton pump Inhibitors.

\begin{tabular}{|c|c|c|c|c|c|c|}
\hline Drug & $\begin{array}{l}\text { Dosage } \\
\text { form }\end{array}$ & $\begin{array}{l}\text { Dose } \\
\text { (mg) }\end{array}$ & $\begin{array}{l}\text { Number of manufacturing } \\
\text { companies }\end{array}$ & $\begin{array}{l}\text { Minimum } \\
\text { price (INR) }\end{array}$ & $\begin{array}{l}\text { Maximum } \\
\text { price (INR) }\end{array}$ & $\begin{array}{l}\text { Price } \\
\text { variation }\end{array}$ \\
\hline \multirow{6}{*}{ Omeprazole } & Tablet & 20 & 5 & 24.50 & 39.60 & $61.63 \%$ \\
\hline & \multirow[t]{3}{*}{ Capsule } & 10 & 5 & 20.00 & 28.98 & $44.90 \%$ \\
\hline & & 20 & 27 & 23.00 & 63.33 & $175.35 \%$ \\
\hline & & 40 & 2 & 65.00 & 73.33 & $12.31 \%$ \\
\hline & EC capsule & 20 & 2 & 39.00 & 54.4 & $39.49 \%$ \\
\hline & Injection & 40 & 2 & 23.25 & 23.75 & $2.15 \%$ \\
\hline \multirow{5}{*}{ Esomeprazole } & \multirow{2}{*}{ Tablet } & 20 & 3 & 17.00 & 35.00 & $105.88 \%$ \\
\hline & & 40 & 7 & 27.00 & 60.00 & $122.22 \%$ \\
\hline & \multirow{2}{*}{ EC tablet } & 20 & 2 & 33.00 & 35.93 & $8.88 \%$ \\
\hline & & 40 & 2 & 55.00 & 56.93 & $3.51 \%$ \\
\hline & Injection & 40 & 3 & 77.00 & 95.75 & $24.35 \%$ \\
\hline \multirow{2}{*}{ Lansoprazole } & \multirow{2}{*}{ Capsule } & 15 & 3 & 21.80 & 26.25 & $20.41 \%$ \\
\hline & & 30 & 8 & 44.00 & 103.00 & $134.09 \%$ \\
\hline \multirow{5}{*}{ Pantoprazole } & \multirow{2}{*}{ Tablet } & 20 & 13 & 18.55 & 58.00 & $212.67 \%$ \\
\hline & & 40 & 67 & 30.00 & 78.00 & $160.00 \%$ \\
\hline & \multirow{2}{*}{ EC tablet } & 20 & 5 & 25.00 & 54.39 & $117.56 \%$ \\
\hline & & 40 & 16 & 13.33 & 80.08 & $500.75 \%$ \\
\hline & Injection & 40 & 52 & 44.80 & 79.50 & $77.46 \%$ \\
\hline \multirow{4}{*}{ Rabeprazole } & Tablet & 20 & 57 & 18.50 & 86.50 & $367.57 \%$ \\
\hline & EC tablet & 20 & 13 & 15.90 & 76.50 & $381.13 \%$ \\
\hline & FC tablet & 20 & 2 & 29.00 & 59.10 & $103.79 \%$ \\
\hline & Injection & 20 & 19 & 50.00 & 89.00 & $78.00 \%$ \\
\hline \multirow{2}{*}{ Dexrabeprazole } & \multirow{2}{*}{ Tablet } & 5 & & 35.00 & 120.00 & $85.56 \%$ \\
\hline & & 10 & & 18.00 & 33.40 & $242.86 \%$ \\
\hline \multirow{2}{*}{ Ilaprazole } & \multirow{2}{*}{ Tablet } & 5 & 2 & 45.00 & 52.00 & $15.56 \%$ \\
\hline & & 10 & 2 & 77.00 & 85.00 & $10.39 \%$ \\
\hline
\end{tabular}

INR: Indian rupees; EC: Enteric coated; FC: Film coated. 
Table 2: Price variation among $\mathrm{H} 2$ blockers used in peptic ulcer.

\begin{tabular}{|c|c|c|c|c|c|c|}
\hline Drug & Dosage form & $\begin{array}{l}\text { Dose } \\
\text { (mg) }\end{array}$ & $\begin{array}{l}\text { Number of manufacturing } \\
\text { companies }\end{array}$ & $\begin{array}{l}\text { Minimum } \\
\text { price (INR) }\end{array}$ & $\begin{array}{l}\text { Maximum } \\
\text { price (INR) }\end{array}$ & $\begin{array}{l}\text { Price } \\
\text { variation }\end{array}$ \\
\hline \multirow{5}{*}{ Ranitidine } & \multirow{2}{*}{ Tablet } & 150 & 7 & 4.82 & 7.60 & $57.68 \%$ \\
\hline & & 300 & 3 & 8.34 & 13.53 & $62.23 \%$ \\
\hline & \multirow{2}{*}{ FC Tablet } & 150 & 2 & 7.25 & 9.00 & $24.14 \%$ \\
\hline & & 300 & 2 & 10.18 & 10.19 & $0.10 \%$ \\
\hline & Injection & 50 & 8 & 2.38 & 25.94 & $989.92 \%$ \\
\hline \multirow{2}{*}{ Famotidine } & \multirow{2}{*}{ Tablet } & 20 & 5 & 3.21 & 16.04 & $399.69 \%$ \\
\hline & & 40 & 5 & 5.03 & 34.86 & $593.04 \%$ \\
\hline \multirow{2}{*}{ Roxatidine } & \multirow{2}{*}{ SR Tablet } & 75 & 2 & 39.25 & 44.65 & $13.76 \%$ \\
\hline & & 150 & 2 & 73.10 & 73.47 & $0.51 \%$ \\
\hline
\end{tabular}

INR: Indian rupees; FC: Film Coated; SR: Sustained Release.

Table 3: Price variation among prostaglandin analogues used in peptic ulcer.

\begin{tabular}{|lllllll|}
\hline Drug & $\begin{array}{l}\text { Dosage } \\
\text { form }\end{array}$ & $\begin{array}{l}\text { Dose } \\
(\mu g)\end{array}$ & $\begin{array}{l}\text { Number of manufacturing } \\
\text { companies }\end{array}$ & $\begin{array}{l}\text { Minimum } \\
\text { price (INR) }\end{array}$ & $\begin{array}{l}\text { Maximum } \\
\text { price(INR) }\end{array}$ & $\begin{array}{l}\text { Price } \\
\text { variation }\end{array}$ \\
\hline Misoprostol & Tablet & 200 & 4 & 61.00 & 69.74 & $14.33 \%$ \\
\hline
\end{tabular}

INR: Indian rupees; $\mu \mathrm{g}$ : Microgram.

Table 4: Price variation among ulcer protectives.

\begin{tabular}{|llllll|l|}
\hline Drug & Dosage form & $\begin{array}{l}\text { Dose } \\
(\mathbf{m g})\end{array}$ & $\begin{array}{l}\text { Number of manufacturing } \\
\text { companies }\end{array}$ & $\begin{array}{l}\text { Minimum } \\
\text { price (INR) }\end{array}$ & $\begin{array}{l}\text { Maximum } \\
\text { price (INR) }\end{array}$ & $\begin{array}{l}\text { Price } \\
\text { variation }\end{array}$ \\
\hline \multirow{2}{*}{ Sucralfate } & Tablet & 1000 & 2 & 15.00 & 39.90 & $166.00 \%$ \\
& Oral suspension & $1000 / 10 \mathrm{ml}$ & 4 & 103.80 & 115.00 & $10.79 \%$ \\
\hline
\end{tabular}

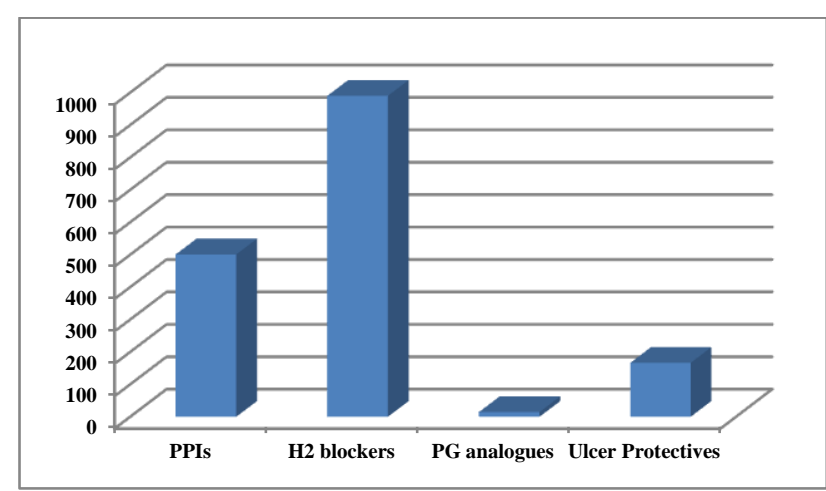

PPIs: Proton pump inhibitors; PG: Prostaglandin.

\section{Figure 1: Maximum price variation among different groups of anti-ulcer drugs.}

Overall, among the various categories of anti-ulcer drugs available in the Indian market, the maximum price variability was seen highest with $\mathrm{H} 2$ blockers (ranitidine 989.92\%) followed by PPIs (pantoprazole - 500.75\%) which was followed by ulcer protectives (sucralfate$166.03 \%)$ and lowest was seen with prostaglandin analogues (misoprostol-14.33 \%) (Figure 1).

Among the proton pump inhibitors, pantoprazole $(40 \mathrm{mg}$; EC tablet) showed the maximum price variation of $500.75 \%$ while omeprazole (40 mg; Injection) showed the minimum price variation of $2.15 \%$ (Table 1 ).
As far as individual PPIs are concerned, the highest price variation with omeprazole was found to be $175.35 \%$ and the least price variation was found to be $2.15 \%$; with esomeprazole, highest was found to be $122.22 \%$ and least was found to be $3.51 \%$; with lansoprazole, highest was found to be $134.09 \%$ and least was found to be $20.41 \%$; with pantoprazole, highest was found to be $134.09 \%$ and least was found to be $20.41 \%$; with rabeprazole, highest was found to be $134.09 \%$ and least was found to be $20.41 \%$; with dexrabeprazole, highest was found to be $134.09 \%$ and least was found to be $20.41 \%$ and finally with ilaprazole, the highest price variation was found to be $15.56 \%$ and the least price variation was found to be 10.39\% (Table 1 and Figure 2).

With regard to $\mathrm{H} 2$ blockers used in peptic ulcer, ranitidine (50 mg; injection) showed the maximum price variation of $989.92 \%$ while ranitidine ( $300 \mathrm{mg}$; FC tablet) showed the minimum price variation of $0.10 \%$ (Table 2 and Figure 3).

As far as individual $\mathrm{H} 2$ blockers are concerned, the highest price variation with ranitidine was found to be $989.92 \%$ and the least price variation was found to be $2.15 \%$; with famotidine, highest was found to be $593.04 \%$ and least was found to be $399.69 \%$ and with roxatidine, the highest price variation was found to be $13.76 \%$ and 
the least price variation was found to be $0.15 \%$ (Table 2 and Figure 2).

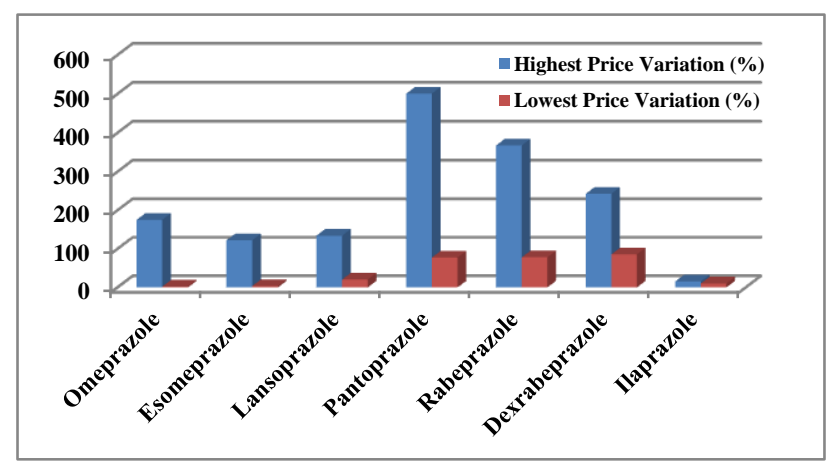

Figure 2: Price variation of various formulations among proton pump inhibitors in India.

In relation to prostaglandin analogues, misoprostol was the only drug available as $200 \mu \mathrm{g}$ tablet and it showed a price variation of $14.33 \%$ (Table 3 ).

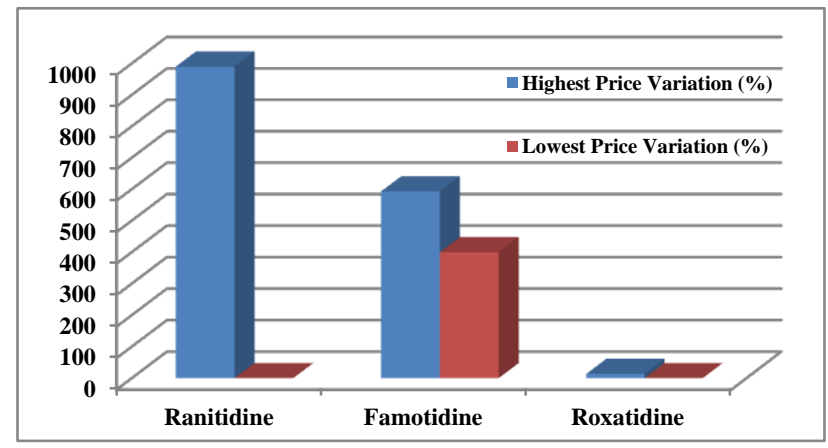

Figure 3: Price variation of various formulations among $\mathrm{H} 2$ blockers in India.

As far as ulcer protectives are concerned, sucralfate was the only drug available. Among its various formulations, the maximum price variation was seen with $1000 \mathrm{mg}$ tablet of $166.00 \%$ whereas minimum price variation was seen with oral suspension $(1 \mathrm{gm} / 10 \mathrm{ml})$ of $10.79 \%$ (Table $4)$.

\section{DISCUSSION}

To the best of our knowledge, there was no study done to evaluate the variability of prices of anti-ulcer drugs in India. Our study for the first time analysed the variation of cost among different brands of anti-ulcer drugs available in the Indian market. Our findings revealed that the prices of various anticancer drug formulations showed great variation.

Stress in various forms has been increased tremendously in the present day society which leads to many diseases including peptic ulcer which can be seen clearly in the tremendous increase in the prevalence of acid peptic disorders in the recent years. ${ }^{10,11}$ Even though many categories of drugs are used in peptic ulcer, PPIs are known to be more efficacious than other anti-ulcer medications and to have a relatively low toxicity, they have become one of the most prescribed drugs worldwide. $^{12,13}$

The cost of anti-ulcer drugs plays a major decisive influence on the availability and utilization of them by the patients especially in resource poor country like India. Cost becomes a concerning factor when these drugs should be used on a long term basis and it can influence the compliance also which will have devastating effects on the health of the population. ${ }^{14}$ Due to lack of information on comparative drug prices and quality, it becomes difficult for physicians to prescribe the most economical treatment. ${ }^{15}$

The difference in cost between the various brands of the same drug varies from two fold to more than 100 fold. ${ }^{16}$ There are various reasons for this price variation which include majority of them being under patent protection and also the present market for new chemical entities being monopolistic in nature. In this market structure, the sellers retain appreciable influence over the price of a product. ${ }^{17}$ Prescribing physicians are usually influenced by information provided to them in the form of formularies, promotional literature and marketing tactics of the medical representatives of that particular brand. The notion that new drug is always better than old drugs is also prevalent among physicians which need not be true always. This kind of biased information restricts both prescribers and patient's choices. ${ }^{17}$

Manufacturing companies claim high cost of research involved in developing new anti-ulcer drugs as a reason for higher pricing of drugs. There are many middlemen involved in the process of a drug reaching to the consumer after it gets manufactured. Even though many times, the manufacturing cost of a particular anticancer drug is less, these middlemen who are involved in distribution and retail sale of drugs because of their bargaining power and based on demand are quite often responsible for high and indiscriminate variability of prices seen among various drugs. ${ }^{18}$

Differences in guidelines of drug regulating authorities of various countries and their pricing policies account for the varying prices of drugs among different countries. Drug price control order (DPCO) is an order issued by the Indian government in 2013 to fix the price of drugs, which covers 680 formulations at present. ${ }^{19}$

Once any medicine is brought under the purview of DPCO, it cannot be sold at a price higher than that fixed by the government. In the past few years, the numbers of medicines that are under DPCO have been decreasing slowly due to which the cost of drugs are escalating. Among anti-ulcer drugs, only five drugs out of the total 12 drugs whose price variation was analysed in this study i.e. omeprazole, pantoprazole, ranitidine, famotidine and misoprostol were included in the national list of essential 
Medicines (NLEM), while many other newer and more effective anti-ulcer drugs were not included in the list. ${ }^{20}$

As mentioned earlier, as the medical insurance is in an emerging stage only in India, majority of the patients should pay the cost of medicines out of their pocket which poses a great financial burden on them. ${ }^{21}$ A substantial part of the medical expenditure is due to drugs alone which again reiterates the need to decrease the cost of medicines in developing countries. ${ }^{22}$

In a developing country like India, one of the smart ways to reduce the prescription costs is to use the generics. Even though the Medical Council of India have insisted on prescribing the generic drugs as far as possible, doctors are reluctant to write prescriptions containing only generic or unbranded chemical name of drugs. All too often, the physicians and the patients prefer the expansive brand name drugs because they believe that the generic equivalent is inferior. Patients have to pay more unnecessarily if costly brands are prescribed. The costly brand of same generic drug is scientifically proved to be in no way superior to its economically cheaper counterpart. $^{23}$

So it becomes the need of the hour by not only government, but also by all the stake holders like NGOs, health care providers and general public to make a concerted effort in order to put pressure on the pharmaceutical manufacturing companies whereby the prices of both branded and generic drugs can be brought down and can be made affordable to common man.

In conclusion, this study shows that there is a wide variation in the prices of most of the anti-ulcer drugs available in India. Health care providers must be aware of availability of low cost brands or generics available among anti-ulcer drugs and prescribe accordingly based on the economic status of the patient for successful treatment of acid peptic disorders. There an urgent need to decrease the wide price variation seen with anti-ulcer drugs by the government in order to decrease the economic burden on population.

\section{ACKNOWLEDGEMENTS}

Our heartfelt thanks to all the other staff of department of pharmacology for their constant support throughout the study without which this study would not be possible.

\section{Funding: No funding sources}

Conflict of interest: None declared

Ethical approval: The study was approved by the Institutional Ethics Committee

\section{REFERENCES}

1. Shin JM, Vagin O, Munson K, Kidd M, Modlin IM, Sachs G. Molecular mechanisms in therapy of acidrelated diseases. Cell Mol Life Sci. 2008;65:264-81.
2. Sandler RS, Everhart JE, Donowitz M, Adams E, Cronin K, Goodman C, et al. The burden of selected digestive diseases in the United States. Gastroenterology. 2002;122:1500-11.

3. Cappell MS. Clinical presentation, diagnosis, and management of gastroesophageal reflux disease. Med Clin North Am. 2005;89:243-91.

4. Meropol NJ, Schulman KA. Cost of cancer care: issues and implications. J Clin Oncol. 2007;25:180-6.

5. Rao KS, Nundy M, Dua AS. National commission on macroeconomics and health. financing and delivery of health care services in India. New Delhi: Ministry of Health and Family Welfare, Government of India, Delivery of Health Services in the Private Sector; 2005:89-104.

6. Sakthivel S. Access to essential drugs and medicines. In: Lal PG (Ed.) National Commission on Macroeconomics and Health. New Delhi: Ministry of Health; 2005:185-210.

7. Jadhav NB, Bhosale MS, Adhav CV. Cost analysis study of oral antidiabetic drugs available in Indian market. Int J Med Res Health Sci. 2013;2(1):63-9.

8. Indian Drug Review (IDR). 2014;21(4).

9. Adam T, Evans DB, Murray CJL. Cost effectiveness and resource allocation. 2003;1:3. Available at http://www.resource-allocation.com/content/1/1/3. Accessed on 11 August 2009.

10. Olkinuora M, Asp S, Juntunen J, Kauttu K, Strid L, Aarimaa M. Stress symptoms, burnout and suicidal thoughts in Finnish physicians. Soc Psychiatry Psychiatr Epidemiol. 2004;25(2):81-6.

11. Yuan Y, Padol IT, Hunt RH. Peptic ulcer disease today. Nat Clin Pract Gastroenterol Hepatol. 2006;3:80-9.

12. Tajima A, Koizumi K, Suzuki K, Higashi N, Takahashi M, Shimada T, et al. Proton pump inhibitors and recurrent bleeding in peptic ulcer disease. J Gastroenterol Hepatol. 2008;23:S237S234.

13. Ntaios G, Chatzinikolaou A, Kaiafa G, Savopoulos C, Hatzitolios A, Karamitsos D. Evaluation of use of proton pump inhibitors in Greece. Eur J Intern Med. 2009;20:171-3.

14. Russell LB, Gold MR, Siegel JE, Daniels N, Weinstein MC. The role of cost-effectiveness analysis in health and medicine: panel on costeffectiveness in health and medicine. JAMA. 1996;276(14):1172-7.

15. Paunikar AP, Bhave KA. Cost analysis of oral antidepressant drugs available in India. Natl J Physiol Pharm Pharmacol. 2015;5(5):367-71.

16. Lofolm PW, Katzug BG. Rational prescribing and prescription writing. In: Katzug BG (Ed.) Basic and Clinical Pharmacology, $9^{\text {th }}$ edn. New York: McGrawHill; 2012:1091-100.

17. Roy V, Gupta U, Agarwal K. Cost of medicines and their affordability in private pharmacies in Delhi (India). Indian J Med Res. 2012;136(5):827-35.

18. Levy-Neumand O, Carniaux F, Bonaz B, Durand A, Roblin X. Proton pump inhibitors in general 
medicine. Comparison of routine practices with marketing authorization indications. Gastroenterol Clin Biol. 2007;31:78-83.

19. Kumar V, Gupta NV, Kumar KA. A comparison between old and latest systems in DPCO. International Journal of Pharmacy and Pharmaceutical Sciences. 2014;6(2):19-20.

20. National List of Essential Medicines of India, 2015. Available at http://mohfw.nic.in/WriteReadData/1892s/736449751 3National\%20List\%20of\%20Essential\%20Medicine, \%202011.pdf. Accessed on 28 March 2015.

21. Creese A, Kotwani A, Kutzin J, Pillay A. Evaluating pharmaceuticals for health policy in low and middle income country settings. In: Freemantle N, Hill S, editors. Evaluating pharmaceuticals for health policy and reimbursement. Massachusetts, USA: Blackwell Publication; (in collaboration with WHO Geneva); 2004:227-43.

22. Mahal A, Karan A, Engelgau M. The economic implications of non-communicable disease for India. Washington, DC: World Bank; 2010. Available at http://www.environmentportal.in/files/NCDforIndia.p df.

23. Das SC, Mandal M, Mandal SC. A critical study on availability and price variation between different brands: Impact on access to medicines. Indian $\mathbf{J}$ Pharm Sci. 2007;69(1):160:3.

Cite this article as: Kolasani BP, Divyashanthi CM. Pharmacoeconomic analysis of drugs used for peptic ulcer in India. Int J Basic Clin Pharmacol 2016;5:1672-7. 